\title{
New editorial office
}

\author{
Yuki Ichinose $^{1}$
}

Published online: 6 December 2019

(c) The Phytopathological Society of Japan and Springer Japan KK, part of Springer Nature 2019

It is a great honor to take over as the Editor-in-Chief of the Journal of General Plant Pathology (JGPP) from Professor Kazuya Akimitsu of Kagawa University as of January 12020 . Our new editorial team would like to express our sincere gratitude to the former editorial team led by Dr. Kazuya Akimitsu for their tremendous efforts to develop the journal. In keeping with their activities, the new editorial board will take responsibility for maintaining the integrity and further improving the quality of the Journal of General Plant Pathology during the next two years.

The Pytopathological Society of Japan (PSJ) was founded in 1916, and the journal run by PSJ was first published in 1918. As the international importance of journals increased, research reports were channeled into an English-based international journal, the Journal of General Plant Pathology, and a Japanese-based journal, the Japanese Journal of Phytopathology, in 2000 from volume 66. The Journal of General Plant Pathology launched an online submission and tracking system in April 2007. This system resulted in a remarkable increase in the submission, publication, and downloading of articles, especially from foreign countries.

The Journal of General Plant Pathology covers all areas plant pathology: plant diseases and their control, including pathogen characterization, identification of pathogens, disease physiology and biochemistry, molecular biology, morphology and ultrastructure, genetics, disease transmission, ecology and epidemiology, chemical and biological control, disease assessment, and other topics relevant to plant pathological disorders. The journal is published bimonthly and welcomes the submission of manuscripts from all areas of plant pathology and related topics. The current Impact Factor for the Journal of General Plant Pathology in the 2018 was 0.887 , which is a slight fall. We believe that the Journal of General Plant Pathology publishes high quality papers. Therefore, we are ready to make further efforts to maintain and raise the Impact Factor.

From the beginning of 2020, the PSJ evolves into a general incorporated association. We will open up the development of phytopathological studies more globally to the whole world. We, the members of the Editorial Board for The Journal of General Plant Pathology, during our twoyear tenure will work to ensure that the Journal continues to advance the Society and our science. We cordially invite you to submit your best research papers to the Journal of General Plant Pathology.

Publisher's Note Springer Nature remains neutral with regard to jurisdictional claims in published maps and institutional affiliations.
Yuki Ichinose

yuki@okayama-u.ac.jp

1 Graduate School of Environmental and Life Science, Okayama University, Okayama, Okayama 700-8530, Japan 